\title{
Landscapes of Prosperity, Youth, Femininity, Temptation, Friendship, Transition, Money, and Survival in Terms of Evolutionary Psychology
}

\author{
Agnieszka Kępkowicz * and Halina Lipińska (10 \\ Department of Grassland and Landscape Studies, University of Life Sciences in Lublin, Akademicka 15, \\ 20-950 Lublin, Poland; halina.lipinska@up.lublin.pl \\ * Correspondence: agnieszka.kepkowicz@up.lublin.pl; Tel.: +48-601-316-425
}

check for updates

Citation: Kępkowicz, A.; Lipińska, H. Landscapes of Prosperity, Youth, Femininity, Temptation, Friendship, Transition, Money, and Survival in Terms of Evolutionary Psychology. Sustainability 2021, 13, 11046. https://doi.org/10.3390/ su131911046

Academic Editor: Richard Ross Shaker

Received: 5 August 2021

Accepted: 29 September 2021

Published: 6 October 2021

Publisher's Note: MDPI stays neutral with regard to jurisdictional claims in published maps and institutional affiliations.

Copyright: (c) 2021 by the authors. Licensee MDPI, Basel, Switzerland. This article is an open access article distributed under the terms and conditions of the Creative Commons Attribution (CC BY) license (https:// creativecommons.org/licenses/by/ $4.0 /)$.

\begin{abstract}
Assessment of landscape attractiveness often struggles with the challenge of differences in human tastes. In the present study, the relationship between preferences shaped by the biological and cultural evolution of mankind and the qualities of landscape attractiveness were examined. The aim of the study was to determine the types of landscape as related to evolutionary behavior patterns and preferences regarding the choice of a partner in different types of relationships. The research hypothesis was that the sets of traits preferred by human partners can be reflected in sets of preferred qualities of landscape attractiveness. The translation of human qualities into qualities of landscape was done through anthropomorphization using the phenomenological method and research techniques based on branding (e.g., the brand personality construct). During the investigation, the following types of landscape attractiveness were identified: Landscape of Prosperity, Youth, Femininity, Temptation, Friendship, Transition, and Money. The developed typological division is a step towards recognizing new sources of preferences for aesthetic and cognitive landscape values. This framework could be interesting for landscape valuation and planning, as well as research on the cultural character of the landscape, as a resource important in the context of sustainable development.
\end{abstract}

Keywords: landscape attractiveness; landscape typology; landscape anthropomorphization; human dimension; biological and cultural heritage

\section{Introduction}

Assessment of a landscape in terms of such an elusive phenomenon as attractiveness almost always collides with the problem of differences in people's tastes and needs. To capture the problem of attractiveness, understood as a feature that arouses interest, desire or attraction to something or someone [1] the following problems were posed with regard to landscape: what are human preferences in experiencing landscape and evaluating it? What can be the sources of preferences for the attractiveness of observed landscapes?

The discussion raised will help to understand the phenomenon of landscape attractiveness as related to various sources of preferences. It will also indicate the aspect of protection of cultural values that could be lost in dynamically changing contemporary landscapes and facilitate optimal planning decisions in sustainable space management.

Research problems outlined in the Introduction fit the trend of humanistic perception, analysis, and description of the landscape [2]. This slightly differs from the approach rooted in the natural sciences, where the starting point is the geo-ecological and biophysical characteristics of the landscape analyzed largely based on statistical and physiographic research of its elements and properties $[2,3]$.

Starting from the approach to the landscape that recognizes man as an almost "geological" driving force, creating, next to the biosphere, a specific noosphere, as described by Vladimir Vernadsky and Pierre Teilhard de Chardin [4] and a holistic view of the landscape [5], as initiated by Tuan [6], a number of researchers have begun to recognize 
this "landscape language" by elaborating to evaluate and classify the attractiveness of the landscape based on holistic concepts of its understanding. They applied various types of intuitive approaches that consisted of interpreting the visual values of space. These values resulted from both historical, social, and architectural conditions, as well as the aesthetic and scenic values of landscapes, seen as diverse geoecological creations [5,7-11].

The humanistic trend is expressed in describing and categorization of space also in terms of user participation in characterizing and interpreting the meanings of the landscape [10-12]. In this approach, people's feelings, expectations, memories, and associations are incorporated into the process of landscape characterization $[6,7,13,14]$.

\subsection{Landscape as a Phenomenon in Humanistic Terms}

The subject of the research was the landscape, described very accurately by Langner [15] as "the total environment made visible". This visualization consists of a structured form composed of material elements and scenery, which are subject to the laws of composition and aesthetic evaluation [13,16-25]. This "visibility" is also perceived through other senses: hearing and smell [26].

However, the landscape is not only perceived [13,27], it is also experienced and felt. One relates to landscape and makes it the subject of one's game of values and the location of one's feelings. On the one hand, they change it; on the other, it evolves under their influence [6,13].

One's attitude to the landscape is the effect of an in-depth experience of space, impacted by its broader environment, as a sequence of events and a memory of past experiences [13]. As an entity closely related to the subject of observation, i.e., a person, the landscape becomes a subjective phenomenon [13,28], and, as stated by Anderson [28], when something is not what it is, but what it seems, it is also an element of postmodern reality. Thus, in addition to the objective reality, as the representatives of the natural sciences would like it, the landscape also becomes "an experienced world", internalized thanks to personal participation in its exploration and experiencing [29]. Carrying with it a number of individual meanings, the landscape also becomes a message, metaphor, and symbol [6,13,30,31]. Its humanistic side is embodied in the image we have of it, not only in the context of a genuine impression or nostalgia, but also in the "consumption": "because they supposedly generate pleasurable experiences that are different from those typically encountered in everyday life" [12].

As Spirn put it [32], it is extremely important that the exploration of such a view of the landscape phenomenon is done by exploring its language with its own syntax, grammar, and metaphors. This language, its grammar and semantics, is formulated by its biological order, human artifacts and their order here and now, as well as our evolutionary roots.

\subsection{Human Preferences in Experiencing and Evaluating Landscape Attractiveness and Their Sources}

Many researchers evaluate the attractiveness of the landscape in terms of human preferences. They apply two perspectives: one refers to the approach to landscape valuation [33-36] and the second explores people's preferences in the assessment and characteristics of the landscape $[6,12,13,24,37-41]$.

The first perspective pays attention to its foundational paradigms. On the one hand, they relate to the differentiation of the categorizing entities themselves, i.e., the observers, seen as professionals or experts, or the so-called ordinary people [33]. On the other hand, they include two views of phenomena: objective and subjective. The objective approach, essentially based on the study of the physical characteristics of the landscape [34], also including additional conditions, e.g., historical, ecological, artistic, or technical, the assessment and the categorizations are aimed at objectifying their results [35]. Taking into account the subjective paradigm of nascent preferences, it was found that landscape quality (including its attractiveness) is a product of the mind and is born in the eye of the observer [34]. Therefore, the perception of space, especially that related to its aesthetic quality, can only be done from a human perspective. Therefore, it is impossible to 
evaluate it fully "objectively". In this approach, a subjective perspective on aesthetics is adopted, in which the criteria of assessment, or division are examined using psychophysical methods [36].

Considering the second perspective, i.e., people's preferences in the assessment and characteristics of the landscape, the authors discuss their different views and their sources. Some ascribe the differentiation to the properties of the scenery, i.e., the compositional side of the landscape and its picturesque nature $[12,24,37,38]$. In exploring what qualities are preferred by people in judging the attractiveness of a landscape (in this case, cities), Lynch [13] pointed to: legibility, coherence, recognizable individuality and landscape imagery. Other authors discussed the differentiation of preferences as rooted in the peculiarities of the people themselves [6,39-41].

As to the sources of human preferences in terms of attractiveness, Aristotle [42] wrote that a person likes what is available to them intellectually and sensually, what can be remembered, and what does not exceed the abilities of their mind. Wojciechowski [43] mentions the system of patterns built by groups of factors, which are developed in the process of distinguishing people as a species. They are related to satisfying instinctive and physiological needs resulting from living in a given social and cultural group and are based on the particular aesthetic sensitivity of the individual, strengthened by professional education. On the other hand, in environmental psychology, human preferences towards natural landscapes are explained by evolutionary mechanisms such as biophilia or topophilia [44]. Evolutionary psychology answers the question of the preferred type of landscape that can be called the Landscape of Survival. This landscape includes water, potential game, and several natural hideouts, similar to African savannas where the evolution of man occurred [45-49]. Other evolutionary psychologists, in turn, challenge this thesis, believing that humans prefer landscapes that are a part of their habitat, or are familiar to them [50,51].

\subsection{Research Objective}

This manuscript highlights the last of the outlined sources of preferences: human evolutionary roots. The authors were especially intrigued by the study of Buss [46], who in the publication "Evolution of desire. Strategies of human mating" [46] focused on the evolutionary process of sexual selection. He extracted mechanisms that explained the diverse human mating strategies, which were the foundation for models of qualities preferred in a partner, depending on the type of relationship.

Recognition of these models prompted the authors to pose further research questions: could the examination of the qualities desired in various types of relationship partners, as described in the study by Buss [46], also point to some qualities of landscape attractiveness? And, taking into consideration the views of Christian [52], Antrop and Van Eetvelde [16] and Simensen et al. [2] as the research is expanded and is recognized through the classification of the occurring phenomena, could such a coincidence yield a new categorization?

The questions posed directed the purpose of research, i.e., selecting the types of landscape attractiveness related to evolutionarily developed sources of preferences, as described in the study by Buss [46]. The research hypothesis assumed that the sets of traits preferred by women and men in partners in various types of relationships, as indicated in the study by Buss [46], will translate into sets of preferred qualities of landscape attractiveness and these, in turn, will become the source of a new typology.

The obtained results confirmed the above hypothesis and six types of landscape were distinguished and characterized: the Landscape of Prosperity, the Landscape of Youth, the Landscape of Femininity, the Landscape of Friendship, the Landscape of Temptation, the Landscape of Friendship, the Landscape of Transition and the Landscape of Money.

\section{Materials and Methods}

The research methodology resulted from the humanistic approach to the subject and primarily took into account research from the human perspective. The methodological steps assigned to this approach were derived from the arsenal of psychophysical methods: 
the holistic and intuitive interpretation of the visual values of the landscape and the space it depicts. The authors also incorporated the resources of memory, associations, and symbols into the process. However, at their core were research findings related to evolutionary psychology and the human evolutionary heritage.

Taking into account the methodical paradigm distinguishing research entities into experts and the so-called ordinary people, as proposed by Daniel and Vining [33], expert judgment impacted the results of the study. The basic mental procedure-the translation of human qualities into the attractiveness of a landscape, was made by the authors of this manuscript who are professional landscape architects. Their expert evaluation was founded on many years of research on landscape assessment and valuation, both from the natural and social point of view, as well as on expert knowledge in this field.

In the first stage of the research, based on Buss [46], the basic types of relationships in the process of human sexual selection were identified (to obtain the most universal research results, Buss and his team conducted extensive social research at the turn of the 21st century among 10,047 women and men aged 14 to 70 years, first in Europe, then on 6 continents and 5 islands). Buss [46] identified two basic types of relationships in sexual selection: committed/permanent relationships (marriage and long-term partners) and short-term/contingent (an affair or a casual, non-committed relationship). Each of these two types of relationships was studied and described according to gender by Buss [46] as well. Based on this four models of qualities preferred in the selection of a partner in a given relationship were distinguished.

Then, the qualities of each of the four models desired by men and women depending on the type of relationship were selected (also taking into account the study by Buss [46]. They were classified according to how often the study participants [46] mentioned them in their statements.

To translate the preferential qualities described above into those related to the attractiveness of the landscape, two main studies were carried out in parallel. The first study was based on the phenomenological reduction method [53,54]. This method, derived from phenomenology, is useful for a deeper and more integrated spatial analyses and landscape design, so important for sustainable development, as pointed out by Petrović and Marriage [55].

The second study was based on the anthropomorphization of space (the metaphor of assigning human characteristics to animals, plants, objects, phenomena, or abstract concepts). The latter research method was based on the building study of the awareness and the brand personality construct study [56]. This method involves the transfer of concepts specific to the human, e.g., power, intelligence, or self-esteem, to the physical form of the designed objects (e.g., cars, perfumes, and clothes).

At first, the essence of the individual qualities described in the four models was selected. Then, an analogy was identified between the essence of these qualities and the qualities describing the landscape. For each of the qualities (shown in Tables 1-4, column A), the following question was formulated: if a given quality were a landscape, what would it be? For example: if people's ability to gather and control resources were a landscape, what would it be? If generosity were a landscape, what would it be? If high status were a landscape, what would it be? If valor were a landscape, what would it be? In total, 85 similar questions were asked (one for each quality), and as a result, 85 qualities of landscape attractiveness were established. The procedure of translating qualities from the "human domain" to the "landscape domain" was intuitive, which is justified in the humanities, according to Simensen et al. [2].

Then, taking into account the essence of each of the qualities described in the individual models, the qualities of landscape attractiveness were developed. Following the above thought procedure, the qualities preferred by partners in particular types of relationships were assigned the corresponding qualities of landscape attractiveness (Tables 1-4, box B). Subsequently, the obtained landscape qualities were analyzed in terms of their affinity. Sets 
of qualities were searched that would form coherent patterns that would translate into specific types of landscape.

The types of landscape selected during the research were assigned sets of qualities related to their attractiveness. Next, by combining a large number of spontaneous ideas invented by the duo of authors, duplicate qualities were removed from the established quality sets and similar and/or complementary qualities were combined.

As a result of the research, several types of landscape attractiveness and their characteristics were obtained. Those characteristics were based on a set of attributes assigned to them. The main outline of each description was based on the qualities recorded in the first item of each model (the preferred qualities in choosing a partner were written in the order proposed in Buss's research [46], starting with the qualities most often selected by respondents). The description of each type is accompanied by photographs presenting their essence. The research undertaken was of an expert nature. First of all, the basic criterion was established: the landscape should contain at least three features described in the characteristics of a given type. The final selection of photographs was based on intuitive and expert judgement resulting from many years of experience in landscape evaluation.

\section{Results}

Based on the study by Buss [46], two basic types of relationships were identified: permanent and contingent. Then, four models of qualities preferred when choosing a partner in a given relationship were distinguished. These are:

1. Model 1. The qualities that women desire in long-term partners (husbands).

2. Model 2. The qualities that men desire in long-term partners (wives).

3. Model 3. The qualities that women desire in short-term partners (an affair or a casual, non-committed relationship).

4. Model 4. The qualities that men desire in short-term partners (an affair or a casual, non-committed relationship).

\subsection{Identification of Landscape Attractiveness Types Based on Models 1-4}

The type that emerged from the distinguished set of qualities described in Model 1. was called the Landscape of Prosperity. In this model, 23 qualities preferred by women in their partners were distinguished, taking into account the long-term relationship (marriage) (Table 1). They were translated into qualities related to the traction of the landscape. They built an image of a landscape that reflects an opulent, friendly, harmonious, and accessible space that is man-controlled, with a number of qualities that indicate its dynamic development, technological advancement, vigor, and grand scale.

Table 1. A presentation of Model 1, which includes sets of qualities preferred by women in long-term partners (husbands) along with the attributes of landscape attractiveness assigned to them (own study).

\begin{tabular}{|c|c|}
\hline $\begin{array}{l}\text { MODEL 1. } \\
\text { Qualities Preferred by Women in } \\
\text { Long-Term Partners (Husbands) } \\
\text { (Adapted from Buss, 2003) }\end{array}$ & Qualities of Landscape Attractiveness \\
\hline A & B \\
\hline ability to collect and control resources & wealthy, man-controlled \\
\hline willingness to share resources & open, accessible, with facilities, good visibility \\
\hline signs of wealth & $\begin{array}{l}\text { the presence of expensive pieces of art and objects indicates the use of expensive } \\
\text { technologies, materials, and good designers }\end{array}$ \\
\hline generosity & $\begin{array}{l}\text { a landscape of a space that is open to people, offering goods that are both the work of } \\
\text { nature and man (flowers, fruit, the value of comfortable rest for free, beautiful smells, } \\
\text { pleasant sounds), as well as beauty, in an accessible way, with no restrictions }\end{array}$ \\
\hline high social position & $\begin{array}{c}\text { "top shelf" landscape-an extraordinary work of nature, beautifully and properly } \\
\text { invested and cared for }\end{array}$ \\
\hline
\end{tabular}


Table 1. Cont.

\begin{tabular}{|c|c|}
\hline $\begin{array}{l}\text { MODEL } 1 . \\
\text { Qualities Preferred by Women in } \\
\text { Long-Term Partners (Husbands) } \\
\text { (Adapted from Buss, 2003) }\end{array}$ & Qualities of Landscape Attractiveness \\
\hline A & B \\
\hline $\begin{array}{l}\text { ambition and diligence enthusiasm } \\
\text { for climbing the career ladder }\end{array}$ & $\begin{array}{c}\text { a landscape with visible technical innovation investments, following the latest trends, also } \\
\text { ideological }\end{array}$ \\
\hline prowess & $\begin{array}{c}\text { visible appreciation victorious battlegrounds, with monuments, obelisks in honor of the } \\
\text { fighters }\end{array}$ \\
\hline good education & $\begin{array}{c}\text { a landscape depicting a space that was designed using the latest IT and AI technologies or } \\
\text { the latest scientific theories }\end{array}$ \\
\hline noticeable potential for the future & $\begin{array}{c}\text { a landscape of space for new investments, with land reserves or aesthetic potential for } \\
\text { future investments }\end{array}$ \\
\hline maturity, emotional stability & $\begin{array}{l}\text { a harmonious and balanced form, functional spatial arrangements, which are } \\
\text { complementary, consistency at all levels; a well-thought-out, predictable landscape }\end{array}$ \\
\hline reliability, responsibility, & $\begin{array}{l}\text { a landscape that embodies a space where proven materials, technologies, and engineering } \\
\text { solutions were used }\end{array}$ \\
\hline intelligence & $\begin{array}{c}\text { a landscape of space, where modern technologies and smart spatial solutions have been } \\
\text { applied; a landscape also with information communicated by architectural forms, artifacts } \\
\text { or street art }\end{array}$ \\
\hline a match, similar views & $\begin{array}{c}\text { a landscape "for me" - just right for today and tomorrow, one that meets one's needs; a } \\
\text { landscape in line with the culture of the people who inhabit it }\end{array}$ \\
\hline amicability & $\begin{array}{l}\text { landscape with no "scratches" and "cracks", depicting a space with many facilities, one } \\
\text { that meets its users half-way; a space without barriers, providing many options to choose } \\
\text { from, offering a number of chordances }\end{array}$ \\
\hline toll size, tall stature & a large- and grand-scale landscape \\
\hline physical strength, athletic build & $\begin{array}{l}\text { large, expressive spatial forms, created both by nature (big trees) and human (strong } \\
\text { dams, large bridges etc) }\end{array}$ \\
\hline good health & \multirow{2}{*}{$\begin{array}{l}\text { a landscape whose natural elements exemplify health, and the anthropogenic ones remain } \\
\text { in good condition }\end{array}$} \\
\hline good physical shape & \\
\hline love and commitment & landscape created with the good of the environment and man in mind \\
\hline faithfulness & $\begin{array}{l}\text { a landscape faithful to its inhabitants, by no means in spite of them; a landscape resulting } \\
\text { from the history of the land, telling a story about people long after they passed away }\end{array}$ \\
\hline support & \multirow{2}{*}{$\begin{array}{l}\text { a friendly landscape (gentle, familiar forms, "smiling" colors, pleasant sounds and smells), } \\
\text { a landscape of space which, thanks to its facilities, supports less able-bodied people, } \\
\text { opens up to different people, meets them halfway; a landscape on a "human" scale }\end{array}$} \\
\hline kindness & \\
\hline sincerity & $\begin{array}{l}\text { a landscape in which elements pretend nothing: concrete is concrete, wood is wood, steel } \\
\text { is steel, plastic is plastic, and natural elements are not transformed because this is their } \\
\text { beauty; a landscape where the structure is fully legible and related to form and function }\end{array}$ \\
\hline
\end{tabular}

In the case of Model 2 (Table 2), 26 qualities were indicated on the basis of the study by Buss [45] as the qualities preferred by men in long-term partners (wives), did not provide as consistent a picture as the quality set in Model 1. After translating the qualities assigned to Model 2 into the qualities of landscape attractiveness, two types were identified: the Landscape of Youth and the Landscape of Femininity. The first was related to the attractiveness of a woman resulting from the charm of youth. The second was associated with motherhood and maturity in a broad sense. 
Table 2. A presentation of Model 2, which includes sets of qualities preferred by men in long-term partners (wives) along with the attributes of landscape attractiveness assigned to them (own study).

\section{MODEL 2.}

Qualities Preferred by Men in

Long-Term Partners (Wives)

(Adapted from Buss, 2003)

\section{A}

physical beauty-healthy, smooth, clean skin, full lips, shiny hair

$$
\text { willowiness }
$$

animated facial expressions

shapely figure communicating a
healthy female
the beauty of the female partner
increasing the male partner's
prestige

fertility, bearing children

caring, thoughtful

tradition

safety

continuation

charm

athletic silhouette

education artifacts and educational elements communicating knowledge, "storytelling" with symbols; a landscape of space equipped with new technologies, AI

a landscape of a space that is open to people, offering goods that are both the work of nature and man (flowers, fruit, rest, beautiful smell, pleasant sound), as well as beauty, in an accessible way, with no restrictions

\begin{tabular}{cc}
\hline honesty & authentic landscape; a landscape of space that hides no unpleasant surprises \\
\hline independence & open, giving a sense of freedom and ease, a landscape that offers many possibilities \\
\hline kindness & $\begin{array}{c}\text { a friendly landscape (gentle, familiar forms, "smiling" colors, pleasant sounds and smells), a } \\
\text { landscape of space which, thanks to its facilities, supports less able-bodied people, opens up } \\
\text { to different people, meets them halfway; a landscape on a "human" scale }\end{array}$ \\
\hline
\end{tabular}

intelligence

a landscape of space, where modern technologies and smart spatial solutions have been applied; a landscape also with information communicated by architectural forms, artifacts or street art

\begin{tabular}{cc}
\hline loyalty & $\begin{array}{c}\text { a landscape faithful to the space and the tradition from which it originates; a landscape not in } \\
\text { spite of the people who are part of it; a landscape of space that allows one to escape and hide }\end{array}$ \\
\hline $\begin{array}{c}\text { landscape with playful forms (land art, street art, sculptures), intended or not; a landscape } \\
\text { that evokes a smile, provokes practical jokes }\end{array}$ \\
\hline $\begin{array}{r}\text { a popular landscape; open-air space visited willingly and in large numbers, where people } \\
\text { like to rest; a landscape of space, which is part of people's lives }\end{array}$ \\
a landscape demonstrating prosperity; fruitful, affluent, varied
\end{tabular}


Table 2. Cont.

\begin{tabular}{|c|c|}
\hline $\begin{array}{c}\text { MODEL } 2 . \\
\text { Qualities Preferred by Men in } \\
\text { Long-Term Partners (Wives) } \\
\text { (Adapted from Buss, 2003) }\end{array}$ & Qualities of Landscape Attractiveness \\
\hline A & B \\
\hline responsibility & a landscape showcasing safety with no risk; peace and solidity \\
\hline spontaneity & the outdoor area is spontaneously visited and enjoyed \\
\hline emotional maturity & $\begin{array}{l}\text { a landscape balanced on every level (both form and content), well-thought by man and } \\
\text { tuned by nature }\end{array}$ \\
\hline willingness to cooperate & $\begin{array}{l}\text { a landscape of combined yin and yang, complementary forms shaped by man, with respect } \\
\text { for its specificity }\end{array}$ \\
\hline & $\begin{array}{l}\text { Model } 3 \text { with its } 16 \text { qualities preferred by women in short-term partners (an affair or a } \\
\text { casual, non-committed relationship) has become a foundation for distinguishing two types } \\
\text { of attractiveness: Landscape of Temptation and Landscape of Friendship (Table 3). The } \\
\text { first type embraced a landscape full of alluring charm, mystery, and surprise, including } \\
\text { romance. The second was related to the landscape, not that much related to the sphere } \\
\text { of desire, but to the sphere of friendship. Its set of qualities represents a friendly, inviting } \\
\text { space for leisure time; a space that is safe and meets one's needs. }\end{array}$ \\
\hline
\end{tabular}

Table 3. A presentation of Model 3, which includes sets of qualities preferred by women in short-term (casual, noncommitted) partners along with the attributes of landscape attractiveness assigned to them (own study).

MODEL 3.

Qualities That Women Desire in

Short-Term Partners (an Affair or a

Casual, Non-Committed

Relationship)

(Adapted from Buss, 2003)

A

a wonderful reaction to a woman

\begin{tabular}{c}
\hline attractiveness \\
\hline interest \\
\hline mystery
\end{tabular}

\begin{tabular}{c}
\hline generosity \\
\hline availability
\end{tabular}

access to resources a landscape that promises space and offers all that is good, further bestowed with comfort hope for a more interesting life and
a high social position

kindness

full understanding

romantic, atmospheric

\section{Qualities of Landscape Attractiveness}

B

meeting one's needs, promising both comfort and beauty, awaiting, inviting; a landscape designed to give the impression of wooing intriguing, surprising, with interesting forms

a landscape with mystery, arousing curiosity. stimulating the imagination, understated, mysterious; secret

a landscape of a space that is open to people, offering goods that are both the work of nature and man (flowers, fruit, the value of comfortable rest for free, beautiful smells, pleasant sounds), as well as beauty, in an accessible way, with no restrictions physically and visually accessible, open views, with inviting, wide entrances and beauty

a landscape of a higher standard than one is used to, which can be used without restrictions a friendly landscape (gentle, familiar forms, "smiling" colors, pleasant sounds, and smells), a landscape of space which, thanks to its facilities, supports less able-bodied people, opens up to different people, meets them halfway; a landscape on a "human" scale landscape with clear cultural codes and familiar plants; panoramas one knows "by heart" a romantic landscape, favoring romantic walks, meetings, and conversations; a picturesque landscape straight from the paintings of the romantic era 
Table 3. Cont.

\begin{tabular}{|c|c|}
\hline $\begin{array}{c}\text { MODEL } 3 . \\
\text { Qualities That Women Desire in } \\
\text { Short-Term Partners (an Affair } \\
\text { or a Casual, Non-Committed } \\
\text { Relationship) } \\
\text { (Adapted from Buss, 2003) }\end{array}$ & Qualities of Landscape Attractiveness \\
\hline A & B \\
\hline sense of humor & $\begin{array}{c}\text { a landscape with playful forms (land art, street art), intended or not; a landscape that evokes a } \\
\text { smile provokes practical jokes }\end{array}$ \\
\hline physically attractive: handsome & a landscape that catches the eye and seduces with its form \\
\hline healthy, in good shape & $\begin{array}{l}\text { a landscape whose natural elements exemplify health, and the anthropogenic ones remain in } \\
\text { good condition }\end{array}$ \\
\hline athletic & a landscape dominated by dynamic forms \\
\hline $\begin{array}{l}\text { providing additional defense and } \\
\text { protection }\end{array}$ & $\begin{array}{c}\text { a landscape speaking of a safe sheltering space; of places that ensure safety despite the raging } \\
\text { elements (piers, breakwaters, bridges, marinas), a fortified landscape }\end{array}$ \\
\hline
\end{tabular}

The starting point for identifying the next types of landscape were the 10 qualities of landscape attractiveness resulting from the translation of the qualities preferred by men in short-term partners (an affair or a casual, non-committed relationship) presented in Model 4 (Table 4).

The qualities of the first demonstrated a similarity to the Landscape of Temptation described in relation to Model 3, as they were also related to physical attraction (maybe more strongly associated with eroticism and even pornography), novelty and mystery.

Based on male preferences, the nature of the Landscape of Temptation tends to maintain a certain level of mystery, seduction, and surprise without delving into the less noble male preferences. A study by Buss [46] left no doubts—-the following were tempting for men in extramarital relationships: lack of emotional dependence and sex for money, as in "he who pays the piper calls the tune". Due to the consistent adherence to Buss's original research [46], the set of qualities of this type of landscape could have become less romantic, but closer to the truth and therefore more interesting. However, despite the aforementioned differences, the authors decided to create a common type of landscape for Models 3 and 4: the Landscape of Temptation.

The second set of landscape attractiveness qualities resulting from Model 4 became part of the landscape type called the Landscape of Transition. Its set of qualities was characterized by impersonality resulting from the universality of space for everyone and for no one. Moreover, it can be easily morphed from one form to another.

The third set of qualities composed the landscape type called the Landscape of Money. It illustrated an attractive commercial space, both profitable and requiring a fee. Following Urry [12], the authors found an interesting contribution to considerations of landscapes, which, despite their noticeable artificiality, attract with the illusion of true beauty. 
Table 4. A presentation of Model 4, which includes sets of qualities preferred by women in short-term (casual, noncommitted) partners along with the attributes of landscape attractiveness assigned to them (own study).

\section{MODEL 4.}

Qualities That Men Desire in

Short-Term Partners (an Affair

or a Casual, Non-Committed Relationship)

(Adapted from Buss, 2003)

\begin{tabular}{|c|c|}
\hline A & B \\
\hline sexual prowess & $\begin{array}{c}\text { a "phallic" landscape with numerous, highly vertical objects (columnar shrubs and trees, } \\
\text { obelisks, towers) or with forms reminiscent of female sexual attributes; evoking erotic } \\
\text { associations }\end{array}$ \\
\hline $\begin{array}{l}\text { sexiness (physical attraction, } \\
\text { novelty) }\end{array}$ & surprising, different; full of attractive, fashionable forms; seductive, inviting \\
\hline mystery & $\begin{array}{l}\text { a landscape with mystery, arousing curiosity. stimulating the imagination, understated, } \\
\text { mysterious, secret }\end{array}$ \\
\hline promiscuity & $\begin{array}{l}\text { landscape promising space for everyone; depicting a transitional space; an instant landscape, } \\
\text { created at times for some people, and at times for others, depending on the needs }\end{array}$ \\
\hline lack of emotional involvement & cool (e.g., winter) landscape, impersonal, "institutional" \\
\hline availability & physically and visually accessible, open wide vistas, inviting entrances \\
\hline youth & $\begin{array}{l}\text { a landscape of space that is full of fresh spring scents (flowering orchards, forests, herbs) and } \\
\text { colors; a landscape of smooth lines, flawless, firm forms, resilient, flexible structures (trees, } \\
\text { buildings) }\end{array}$ \\
\hline intense interest & $\begin{array}{l}\text { a landscape interested in the observer, establishing contact with them; windows and } \\
\text { viewpoints inviting peeking; a postcard landscape awaiting interest and reaction (even in the } \\
\text { form of a photo) }\end{array}$ \\
\hline $\begin{array}{l}\text { sex without the payment of } \\
\text { commitment }\end{array}$ & landscape for everyone, "by the way" \\
\hline sex for money & a landscape that gives a lot to whoever pays for it \\
\hline
\end{tabular}

\subsection{Characteristics of the Obtained Types of Landscape Attractiveness}

For each of the selected types of landscape attractiveness: Prosperity, Youth, Femininity, Temptation, Friendship, Transition, and Money, its characteristics have been developed.

The set of seven types of landscape attractiveness presented above has been enriched with another eighth type, called the Landscape of Survival. This type, although derived from Buss [46], doesn't result from an analysis of human matchmaking strategies, but from natural selection. The reason for including it in the list was to complete the picture of preferences in assessing the attractiveness of a landscape resulting from our evolutionary roots.

Landscape of Prosperity (Figure 1a,b) personifies, above all, affluent abundance and gives the impression of being friendly and accessible to people. It also has a humancontrolled order, based on professionalism and purposefulness. This kind of landscape is also characterized by the presence of expensive pieces of art and objects indicating the use of smart technologies and materials, as well as the participation of the best designers and artists. All this makes the Landscape of Prosperity perceived as a "high-end" landscape, better than the one we are used to. 


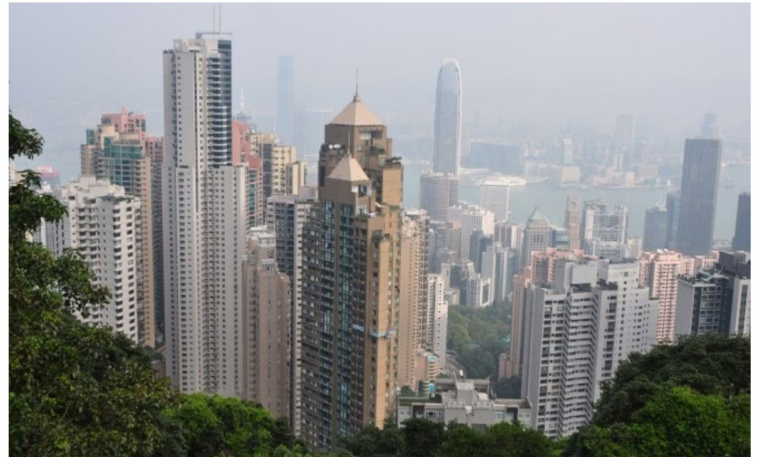

(a)

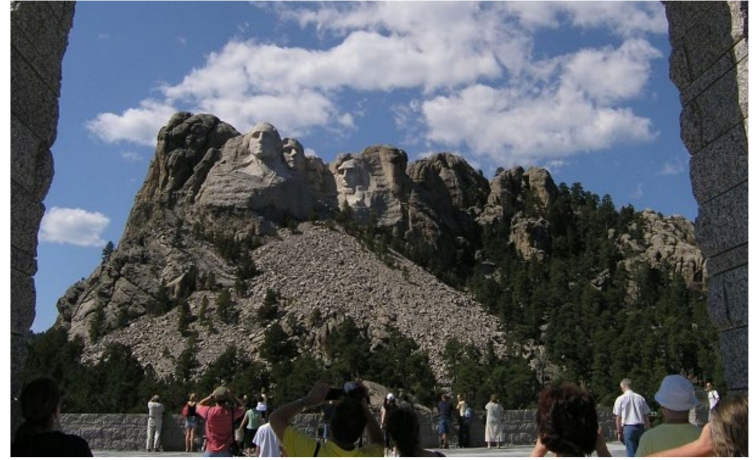

(b)

Figure 1. An exemplary Landscape of Prosperity: (a) View of Hongkong, (photo: A. Kepkowicz, 2010), (b) Heads of American presidents sculpted in rock, Mount Rushmore, South Dakota, USA (photo: A. Kępkowicz, 2005).

It is a landscape that expresses noticeable potential, however, not through its shortcomings (the elements of the Landscape of Prosperity are always presentable and in good technical condition), but through the spatial reserve of attractive land or the initiated investments.

The Landscape of Prosperity is depicted by a space that is characterized by maturity: a harmonious and complementary system, consistent at all levels, protected and created with the good of both the environment and man in mind. On the one hand, it consists of a beautiful, balanced form, systemic functionality, and comfort of use. On the other hand, it includes the use of modern technologies in line with the latest trends in space planning (e.g., smart city solutions, outdoor advertising).

The Landscape of Prosperity functions on a grand scale rather than in an intimate arrangement. The elements of the composition are expressive, coming both from the natural world (rocks, big old trees) and from the arsenal of human craftsmanship (strong dams, large bridges, etc.). They are also built of durable and "honest" materials, where concrete is simply solid concrete, and wood is simply well-used wood.

It is a landscape that also embodies valor by honoring the places of victorious combat with monuments, obelisks in honor of the combatants, or appropriate scenery.

The Landscape of Prosperity is also faithful to its inhabitants; it does not exist in spite of them. It follows the history of the land of which it is a part and tells about people long after their lives or times have passed away.

Landscape of Youth (Figure 2a,b) embodies the appeal of youthful charm, not devoid of eroticism, the grace of free natural movement, virginity, "girlishness" of colors, freshness of fragrance. It also comprises the beauty of a "healthy" space, with no wounds or disfigurement, and the fluid dynamics of form. With its open character, it gives a sense of freedom and ease.

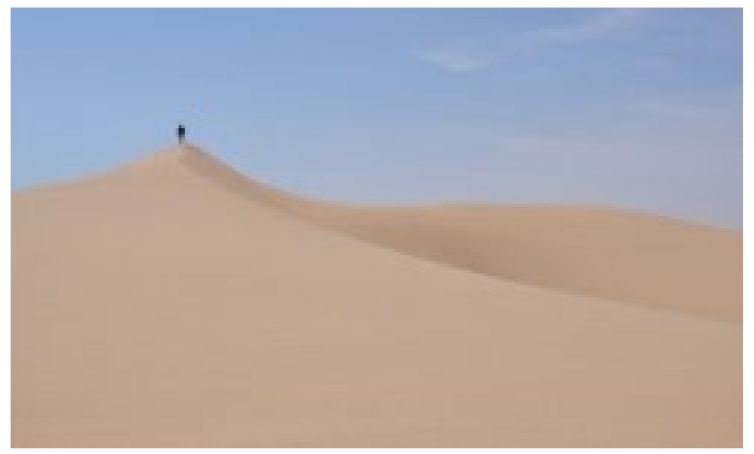

(a)

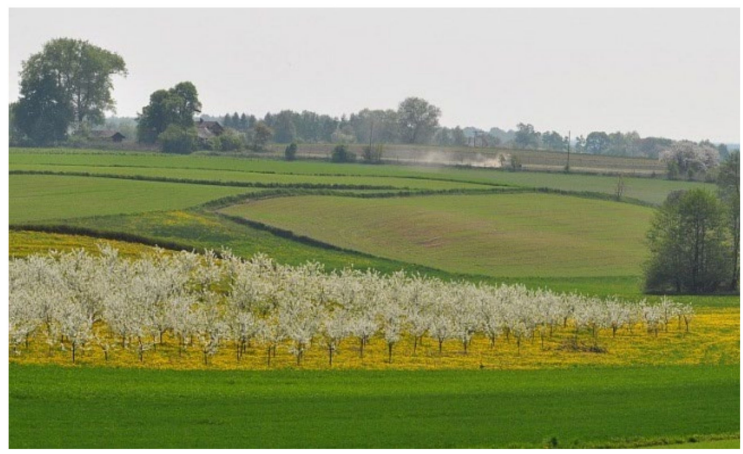

(b)

Figure 2. An exemplary Landscape of Youth: (a) Namib Desert, Namibia (photo: A. Kepkowicz, 2010), (b) spring landscape of Piotrowice near Nałęczów, Poland (photo: K. Olszak, 2012). 
Apart from nature, it is also an anthropogenic landscape, whose modernity and attractiveness of fashionable forms arouse the desire to join it, to appear in it, and to own it. The Landscape of Youth also shares a beauty that raises the prestige not only of the space itself, but also of those who use it or own it.

It embodies a space that does not shy away from technology and smart solutions. It is also a landscape that "communicates" via, e.g., architectural forms, artifacts, or street art.

Landscape of Femininity (Figure 3a,b) is characterized by fertile abundance, enchanting with the saturated beauty of maturity. It is filled with beautiful scents and pleasant sounds. It is a landscape of space that brings comfort and nourishes, accompanied by calming forms. It is a landscape that is unoppressive, conflict-free, soothing, a landscape of space that offers shelter, integral with people who are part of it in terms of tradition and mentality.

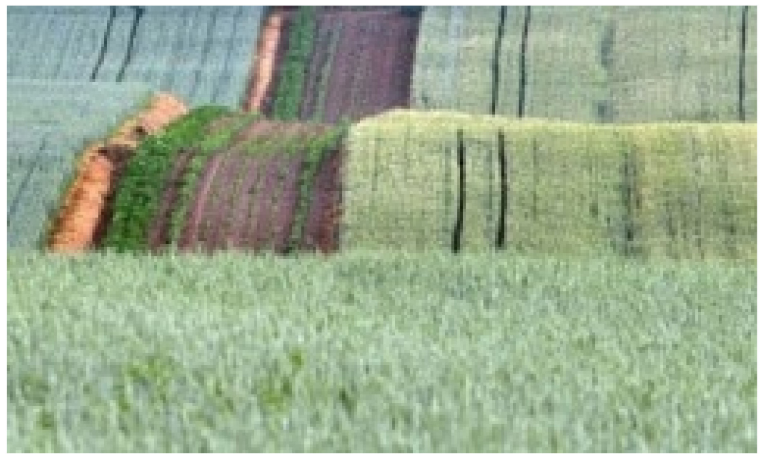

(a)

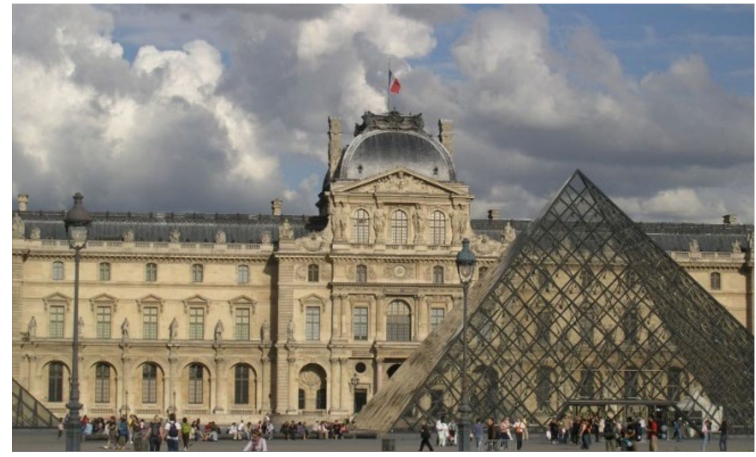

(b)

Figure 3. An exemplary Landscape of Femininity: (a) Arable fields in Bronki near Nałęczów, Poland (photo: K. Olszak, 2011), (b) the Louvre, complemented by its famous pyramid, Paris (photo: A. Kępkowicz, 2005).

The Landscape of Femininity brings to mind childhood, arouses nostalgia. It connects with tradition not only through traditional forms, but also with the continuation of the tradition. Its forms overlap each other. It is an evolving landscape, faithful to the tradition from which it originates, in which the new meets the old and flows from it.

It is also a wise landscape, illustrating a well-thought-out, purposeful space, equipped with artifacts and educational elements communicating knowledge, "storytelling" also with symbols.

The landscape of space, which, thanks to its facilities, opens up to different groups, supports less able-bodied people, meets them halfway.

It is a landscape of an authentic space, not hiding any unpleasant surprises, offering peace and reliable safety without risk.

The Landscape of Femininity is balanced on every level, well thought out, in tune with nature. It combines complementary forms, creatively shaped with respect for their specificity.

Landscape of Temptation (Figure $4 a, b$ ) is a landscape of the forbidden fruit and the anticipation of adventure; a landscape tempting with mystery, surprising with otherness, awakening the desire to conquer, stimulating the imagination; a landscape that is understated, mysterious, secretly hidden, It is a landscape that attracts the eye and seduces with its form; it is intriguing, surprising, better than everyday life; a landscape where everything can be "different", sometimes "fairy tale-like". 


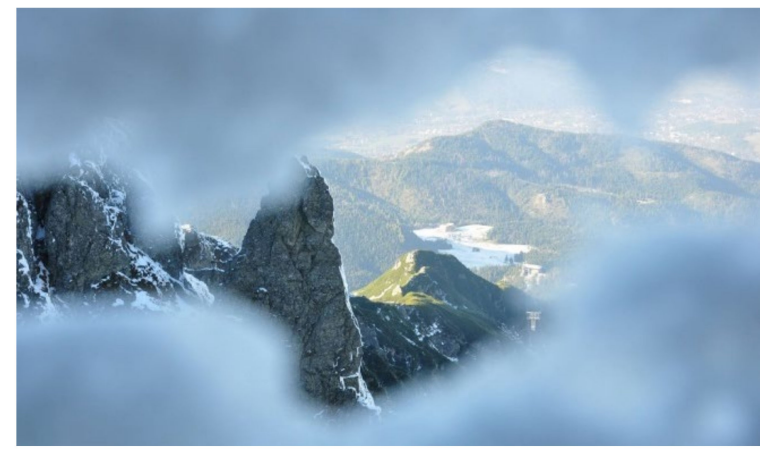

(a)

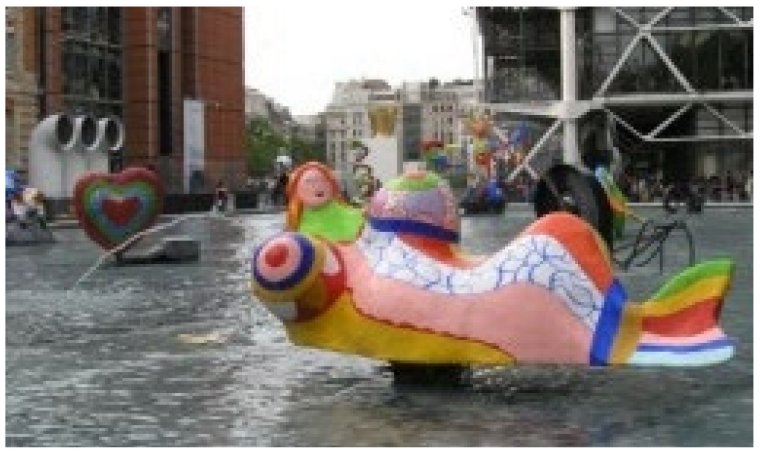

(b)

Figure 4. An exemplary Landscape of Temptation: (a) panorama of the Tatry Mountains, view from the cable car to the top of Mt. Kasprowy Wierch (photo: A. Kępkowicz, 2011), (b) Urban landscape at Centre Georges Pompidou, Paris (photo: A. Kępkowicz, 2009).

When combining the Landscape of Temptation with the human desire for love, one cannot fail to mention its romantic variety: a landscape conducive to romantic walks, meetings, and conversation. It is also a picturesque landscape, straight from the paintings of the masters of the Romantic era.

Combined with eroticism, it can also be a "phallic" or "vaginal" landscape evoking erotic or even pornographic associations.

Landscape of Friendship (Figure 5a,b) meets one's needs, announcing both comfort and beauty. A landscape of space that awaits and invites, one designed to give the impression of wooing. It is also a landscape of a space that is open to people, offering goods that are both the work of nature and man.

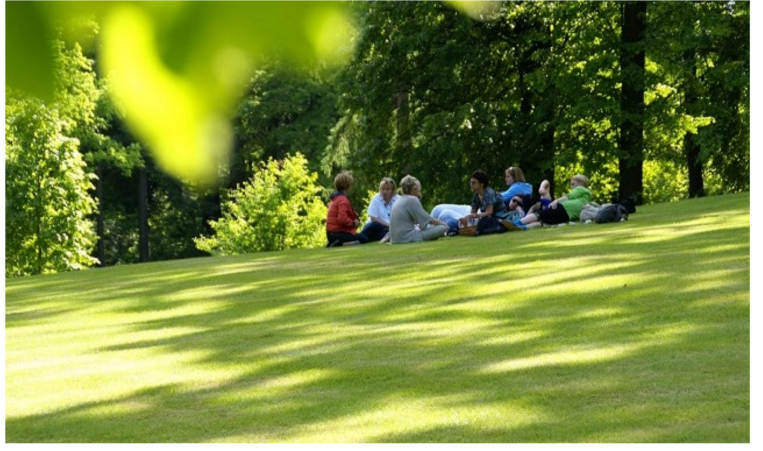

(a)

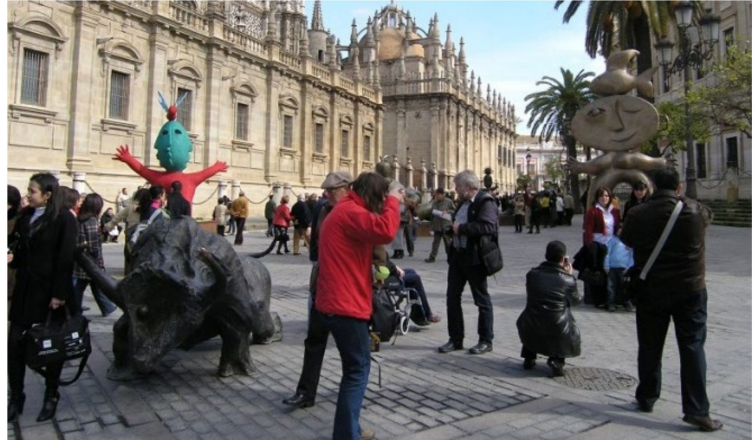

(b)

Figure 5. An exemplary Landscape of Friendship: (a) Park by the palace in Staniszów Górny, Lower Silesia, Poland (photo: J. Dauksza, 2011), (b) Urban square with sculptures in Seville, Spain (photo: A. Kepkowicz, 2009).

Although it can sometimes have a higher standard than what one is used to, one can use it without restrictions. It is physically and visually accessible, with open vistas and broad entrances.

It is also a landscape full of friendly colors, sounds, and smells, a landscape of a "human" scale; a landscape with clear cultural codes and familiar plants, as well as panoramas known "by heart".

The Landscape of Friendship does not shy away from playful forms, intentional or not (land art, street art, digital space-time gates), makes one smile, and provokes practical jokes. The availability of such open-air locations makes it popular; it is frequently and willingly visited, and it becomes a part of people's lives.

Landscape of Transition is an impersonal landscape, a promising space for everyone, and for none in particular. It illustrates a transitional space, treated as a service and without emotions. It is a landscape of institutional space, noticed incidentally and "by the way"; a 
seamless landscape. It is also an "instant" landscape-a space that is created sometimes for some people, and sometimes for others, depending on the needs. It is a landscape that does not arouse emotions and is hardly noticed (that is why it was not depicted with photographs - it was not included in the photographic archives of the authors or their friends).

Landscape of Money (Figure 6a,b), it is a landscape that is available, yet owned by someone else, and which requires payment. This includes the so-called tourist landscapeone that awaits, is prepared for one's arrival, purposefully arranged, and retouched. It is often an exotic landscape to "score", admire, and leave to return home.

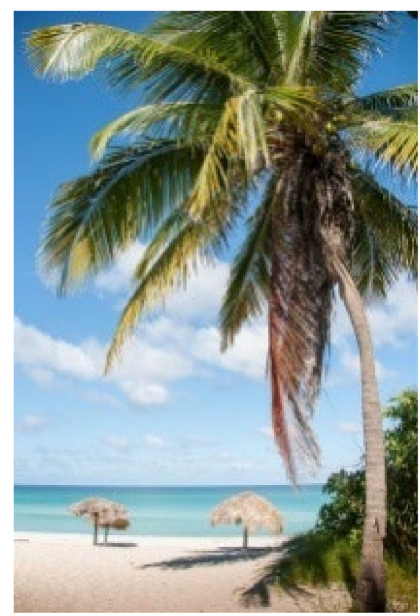

(a)

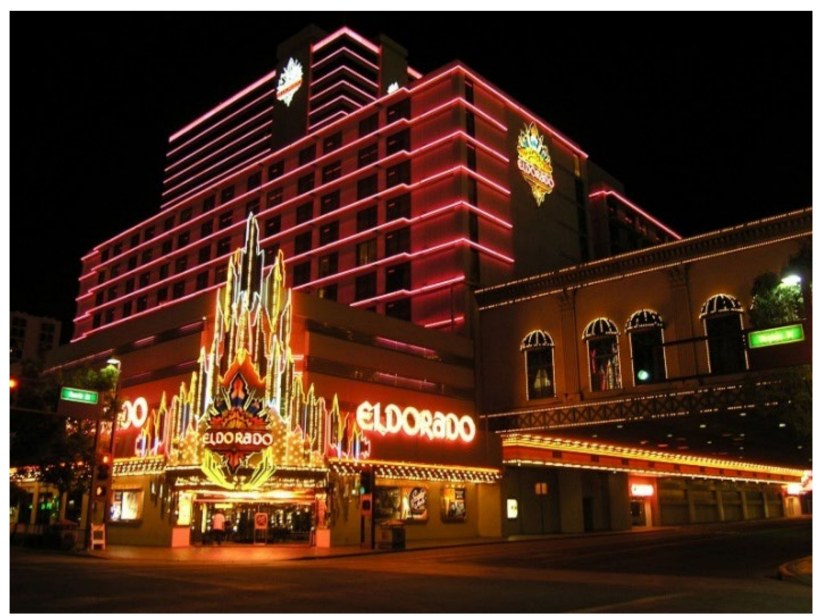

(b)

Figure 6. An exemplary Landscape of Money: (a) The "wild" beach tourist attraction in Varadero, Cuba (photo: A. Strykowska, 2013), (b) Reno, the City of Casinos, Nevada, USA (photo: A. Kepkowicz, 2005).

It is also a landscape full of paid attractions, the prime example of which can be the kingdom of forbidden and paid places: Las Vegas.

Landscape of Survival is not connected, as the landscapes listed landscapes, with human sexual selection, but with the survival instinct (Figure 7a,b). In light of evolutionary psychology research, many representatives of our profession have recognized it as particularly desirable because it is an echo of an ancient human habitat. What distinguishes this type of landscape is the varied topography, rich natural flora, access to natural clean water reservoirs, and the presence of wild animals.

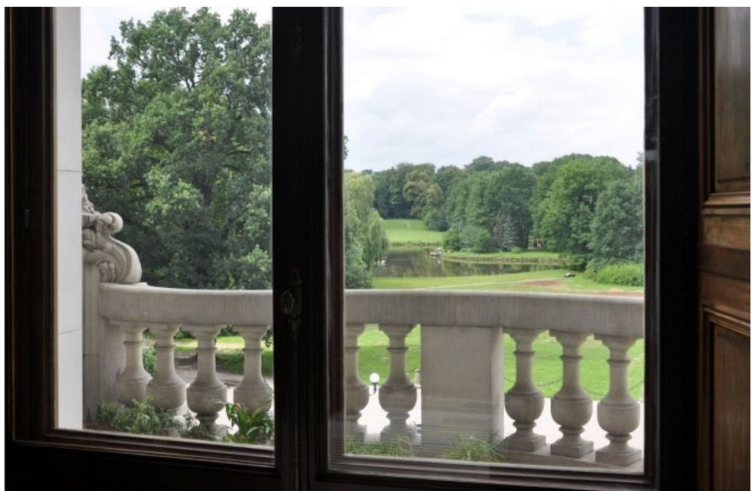

(a)

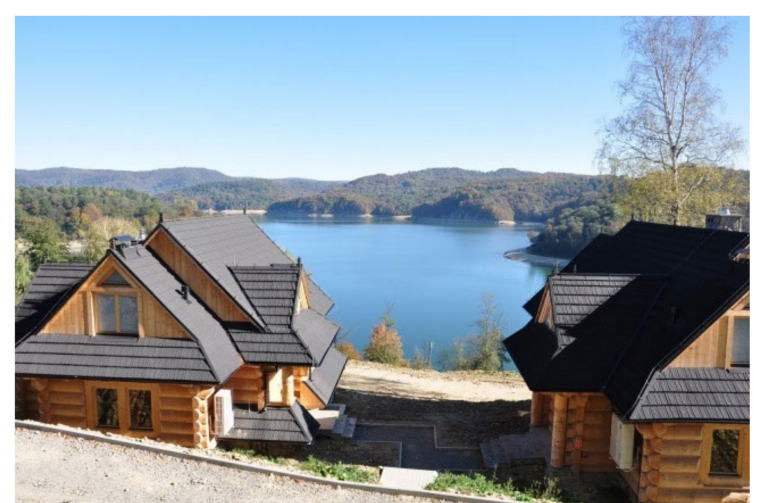

(b)

Figure 7. An exemplary Landscape of Survival: (a) 19th-century English-style landscape park, Pszczyna, Poland (photo: A. Kepkowicz, 2009), (b) Example of development pressure in areas of nature-based attractiveness near a national park, Bieszczady, Poland (photo: A. Kępkowicz, 2017). 


\section{Discussion}

The multidisciplinary nature of landscape research implies different systems and methods for landscape identification and classification. They are rooted in different traditions, and most notably in disciplines such as geography, geology, geomorphology, ecology, history, archeology, and landscape architecture. The findings presented in this publication show yet another source of human preference in assessing the attractiveness of a landscape-our evolutionary roots both biologically and culturally originating from extremely powerful evolutionary mechanisms—sexual selection [46].

The new method of space anthropomorphization developed by the authors leveraged the phenomenological idea of brand personality [56], effectively translating the features in human mating partners into the attractiveness of the landscape attractiveness. The developed types of landscape attractiveness: Prosperity, Youth, Femininity, Temptation, Friendship, Transition, and Money broadened the knowledge of the complexity of the relationship between landscape and man, also in such an ephemeral sphere as feeling and experiencing the landscape [13,27]. What helped was the categorization treatment, which as emphasized by Christian [52], Antrop and Van Eetvelde [16] and Simensen et al. [2], allows to recognize and deepen this phenomenon in a more systematic way. The resulting categorization thus became a step towards recognizing the language of landscape, as intended by Spirn [32]. Also, the types of landscape distinguished in the course of this study expand in a peculiar way the resource of noosphere-the meaningful perception and feeling of space [16].

The discussed research was based on the approach suggested by Wojciechowski [43] more than on Lothian [34], Bell et al. [37], Tveit et al. [24], Sevenant and Antrop [38], or Urry [12]. The preferred qualities of landscape attractiveness resulted from a deeper source than the "eye of the beholder" itself [34]. This means that in addition to people's preference for forms that are easily assimilated [42] and considered interesting because of a person's social role, profession or personal tastes, there are also forms with other sources of preference. This source may be our evolutionary heritage, a heritage that not only relies on biological mechanisms such as biophilia and topophilia [44] or natural selection [46], but also social human mating strategies.

Some of the landscape types identified are similar to those described by other authors. For example, Lynch [13] wrote about the power of the Manhattan landscape, which can classify it as a Landscape of Prosperity. On the other hand, Urry [12] writes about a commercial landscape designed to fulfill the dreams of the tourist-how similar this is to the Landscape of Money. Upon comparing the preferred landscape attractiveness qualities described by Lynch [13] with the qualities obtained as a result of these studies, it should be noted that they are not mutually exclusive. Indicated by Lynch [13], qualities describing the attractiveness of the urban landscape: legibility, coherence, recognizable individuality, and vividness, mainly speak of the structure of forms that build the landscape, and their mutual relations. However, they do not ignore the meanings that they can carry within. These qualities, however, mainly relate to the structures observable in the landscape. Here, beauty is largely born "in the eye of the beholder" [34]. The division criteria proposed by the authors are based on other premises, i.e., the preferences of landscape attractiveness result from our evolutionary heritage as a biological and social species.

Taking into account the key stage of the research, i.e., to translate the qualities describing human preferences in the selection of partners into the preferred qualities of the landscape and the related space, extending the research path seems justified. It would require forming a team of researchers from different disciplines to pursue the research goal. Then, the obtained results would not be a result of assessment of experts representing just one discipline, but the product of broader, multi-faceted negotiations. Bearing in mind the differentiation of preferences in the perception of the landscape due to the specific properties of the people themselves, as emphasized by Tuan [6], Kaltenborn and Bjerke [39] and Erikstad et al. [41], it is possible to indicate further direction of the research undertaken by the authors. 
The paper presents eight types of landscape attractiveness. What could be interesting is a survey to answer the question of what landscapes do the respondents associate with these types. The responses would then be compared with people from different age groups, cultures, and regions. On the one hand, this will contribute to the objectivity of the research results. On the other hand, taking into account the multiplicity of statements, it will enhance its qualitative dimension.

\section{Conclusions}

The answer to the first of the research problems-what are human preferences in experiencing and evaluating landscape attractiveness-was the exploration of this problem by means of the categorization procedure.

The second problem: from what sources can preferences for the attractiveness of observed landscapes arise, was answered in research based on evolutionary psychology, and more specifically from Buss's [46] research on human matchmaking strategies.

The underlying formulas used determined the initial set of characteristics of human preferences. They were then the foundation for determining the quality preferences for landscape attractiveness.

The results of Buss' study [46] contributed to outlining the set of landscape attractiveness qualities that people desire. As a result, a typology was created that proved there are landscapes people can find attractive because of some of their sets of qualities resulting from our evolutionary heritage.

The hypothesis has been confirmed that the sets of traits resulting from research on human mating strategies identified in Buss' study [46] can translate into sets of preferred qualities of landscape attractiveness. During the research, the following types of landscape attractiveness were identified:

Landscape of Prosperity

Landscape of Youth

Landscape of Femininity

Landscape of Temptation

Landscape of Friendship

Landscape of Transition

Landscape of Money.

Thus, the goal of selecting the types of landscape attractiveness based on the qualities desired in partners depending on the nature of the relationship was achieved. The approach proposed by the authors is distinguished by the novelty of the research path taken, which consists of introducing the evolutionary psychology criteria of human mating to landscape preference. So far, the categorization of landscape attractiveness has been derived mainly from aesthetics, geography, geology, geomorphology, ecology, history, archaeology, and landscape architecture. The study undertaken shifts the view of looking at preferences that have impacted the evolution of humans as a species.

The typological division is the next step in discovering and learning what is behind the slogan of attractiveness and beauty of the landscape. It also emphasizes the importance of values and meaning embedded in the landscape and develops new ways of seeking attractiveness in the landscape. The proposed typology also indicated the importance of meaningful landscape values. The use of evolutionary psychology in terms of human mating, an unusual source of research inspiration in the field of landscape attractiveness analysis, can encourage the development of new areas of research for the criteria for assessing landscape attractiveness. The developed typological division will launch a discussion on how to combine the conclusions of evolutionary psychology researchers with broadly understood landscape assessment.

The obtained theoretical knowledge will allow its practical application in strategic landscape planning, to study the preferences of space users in terms of landscape attractiveness in terms of preferences of its "consumers". It will also constitute the next step toward a better understanding of the phenomenon of landscape attractiveness and the sources of 
its preferences. The types identified and their characteristics will serve to raise awareness that the different types of landscape attractiveness, though different, are not necessarily better or worse, more or less valued; they are equivalent. It will also draw attention to the fact that the so-called "taste" can result from more diverse sources of preferences than e.g., individual sense of aesthetics.

The issues discussed in this manuscript do not exhaust the vast and difficult topic of human priorities in terms of assessing the attractiveness of a landscape. It enriches the discussion by pointing out that our preferences can come from various sources, including our evolutionary and cultural roots. Awareness of this resource will also inform sustainable landscape management.

Author Contributions: Conceptualization, Data curation, Formal analysis, Investigation, Methodology, Project administration, Resources, Supervision, Writing—original draft, A.K.; Funding acquisition, Investigation, Resources, Validation, Writing-review \& editing, H.L. All authors have read and agreed to the published version of the manuscript.

Funding: This research received no external funding.

Institutional Review Board Statement: Not applicable.

Informed Consent Statement: Not applicable.

Data Availability Statement: This study did not report any data.

Conflicts of Interest: The authors declare no conflict of interest.

\section{References}

1. Ortony, A.; Clore, G.L.; Collins, A. The Cognitive Structure of Emotions; Cambridge University Press: Cambridge, UK, 1988.

2. Simensen, T.; Halvorsen, R.; Erikstad, L. Methods for landscape characterisation and mapping: A systematic review. Land Use Policy 2018, 75, 557-569. [CrossRef]

3. Michalik-Śnieżek, M.; Chmielewski, S.; Chmielewski, T.J. An introduction to the classification of the physiognomic landscape types: Methodology and results of testing in the area of Kazimierz Landscape Park (Poland). Phys. Geogr. 2019, 40, $384-404$. [CrossRef]

4. Lavrenova, O. Spaces and Meanings, Semantics of the Cultural Landscape; Springer: Cham, Switzerland, 2019.

5. Girot, C. Four trace concepts in landscape architecture. In Recovering Landscape: Essays in Contemporary Landscape Architecture; Ptinceton Architectural Press: New York, NY, USA, 1999; pp. 59-68.

6. Tuan, Y.F. Space and Place: The Perspective of Experience; University of Minnesota Press: Minneapolis, MN, USA, 1977.

7. Swanwick, C. Landscape Character Assessment. Guidance for England and Scotland; The Countryside Agency/Scottish National Heritage: Edinburgh, UK, 2002.

8. Associates, M.J.; Swanwick, C. Overview of Scotland's National Programme of Landscape Character Assessment; Scottish Natural Heritage Commissioned Report F03, AA307; The Scotish LCA Programme, Scotland. 2003. Available online: https: / / www.nature.scot/sites/default/files/2017-07/Publication\%202004\%20-\%20SNH\%20Commissioned\%20Report\%2029 \%20-\%20Overview \%20of\%20Scotland\%27s\%20national\%20programme\%20of\%20Landscape\%20Character\%20Assessment.pdf (accessed on 16 September 2021).

9. Groom, G. Methodological review of existing classifications. In European Landscape Character Areas-Typologies, Cartography and Indicators for the Assessment of Sustainable Landscapes; Wascher, D.M., Ed.; Final ELCAI Project Report; LANDSCAPE EUROPE in collaboration with ELCAI project partners; Landscape Europe: Wageningen, The Netherlands, 2005; pp. 32-45.

10. Raymond, R.; Luginbuhl, Y.; Seguin, J.-F.; Cedelle, Q.; Grare, H. Landscape AtlasesLandscape Identification, Characterisation and Assessment Method; Rapport de Recherche; Ministère de l'Écologie, du Développement durable et de l’Énergie: La Défense, France, 2015.

11. Nogué, J.; Sala, P.; Grau, J. The Landscape Catalogues of Catalonia: Methodology; Landscape Observatory of Catalonia: Catalonia, Spain, 2016.

12. Urry, J. The Tourist Gaze; Lancaster University: Lancaster, UK, 2011.

13. Lynch, K. The Image of the City; M.I.T. Press: Cambridge, MA, USA, 1960.

14. Keighren, I.M.; Withers, C.W.J. The spectacular and the sacred: Narrating landscape in works of travel. Cult. Geogr. 2012, 19, 11-30. [CrossRef]

15. Langer, S. Feeling and Form: A Theory of Art; ScribnerL: New York, NY, USA, 1953

16. Antrop, M.; Van Eetvelde, V. Landscape Perspectives. The Holistic Nature of Landscape; Springer: Dordrecht, The Netherlands, 2017; p. 23.

17. Sauer, C.O.; Leighly, J. (Eds.) The morphology of landscape. In Land and Life; University of California Press: Berkely, CA, USA, 1974; pp. 315-350. 
18. Granö, J.G.; Granö, O.; Paasi, A. (Eds.) Pure Geography; The Johns Hopkins University Press: Baltimore, MD, USA, 1929.

19. Litton, R.B. Aesthetic Dimensions of the Landscape; John Hopkins University Press: Baltimore, MD, USA, 1972.

20. Berg, L.D.; Cosgrove, D.E. Social formation and symbolic landscape. In Progress in Human Geography; Barnes and Noble: Totawa, NJ, USA, 1985; Volume 29, pp. 475-482.

21. Zube, E.H.; Sell, J.L.; Taylor, J.G. Landscape perception: Research, application and theory. Landsc. Plan. 1982, 9, 1-33. [CrossRef]

22. Zube, E.H. Themes in landscape assessment theory. Landsc. J. 1984, 3, 104-110. [CrossRef]

23. Bourassa, S.C. The Aesthetics of Landscape; Belhaven Press: London, UK, 1991.

24. Tveit, M.; Ode, L.; Fry, G. Key concepts in a framework for analysing visual landscape character. Landsc. Res. 2006, 31, 229-255. [CrossRef]

25. Plieninger, T.; Kizos, T.; Bieling, C.; Dú-Blayo, L.L.; Budniok, M.-A.; Bürgi, M.; Crumley, C.L.; Girod, G.; Howard, P.; Kolen, J.; et al. Exploring ecosystem-change and society through a landscape lens: Recent progress in European landscape research. Ecol. Soc. 2015, 20, 5. [CrossRef]

26. Koblet, O.; Purves, R.S. From online texts to Landscape Character Assessment: Collecting and analysing first-person landscape perception computationally. Landsc. Urban Plan. 2020, 197, 103757. [CrossRef]

27. Council of Europe. European Landscape Convention; CETS No. 176; Council of Europe: Strasbourg, France, 2000; Available online: http://www.coe.int/t/dg4/cultureheritage/heritage/Landscape/default_en.asp (accessed on 16 January 2021).

28. Anderson, W.T. Reality Isn't What It Used to Be: Theatrical Politics, Ready-To-Wear Religion, Global Myths, Primitive Chic, and Other Wonders of Postmodern World; Harper\&Row: San Francisco, CA, USA, 1990.

29. Angiel, J.; Hibszer, A.; Szkurłat, E. Zajęcia Terenowe W Kształceniu Geograficznym Od Teorii I Idei Dydaktycznych Do Praktyki Szkolnej (Field Classes in Geographic Education from the Theory and Didactic Ideas to School Practice); Bogucki Wydawnictwo Naukowe: Poznań, Poland, 2020.

30. Madurowicz, M. (Ed.) Percepcja Wspótczesnej Przestrzeni Miejskiej (Perception of Contemporary Urban Space); Wydział Geografii i Studiów Regionalnych UW: Warszawa, Poland, 2007.

31. Myga-Piątek, U. Krajobrazy kulturowe, aspekty ewolucyjne i typologiczne (Cultural Landscape, Evolutionary and Typological Aspects); Uniwerytet Ślaski: Katowice, Poland, 2012.

32. Spirn, A.W. Language of Landscape; Yale University Press: New Haven, CT, USA, 2000.

33. Daniel, T.C.; Vining, J. Methodological issues in the assessment of a landscape quality. Hum. Behav. Environ.Behav. Nat. Environ. 1983, 6, 39-84.

34. Lothian, A. Landscape and Philosophy of Aesthetics: Is Landscape Quality Inherent in the Landscape or in the Eye of the Beholder? Landsc. Urban Plan. 1999, 44, 177-198. [CrossRef]

35. Belcakova, I. Approaches to Evaluation of Landscape Scenery-A Conceptual Contribution. In Proceedings of the 14th International Forum of Studies, Naples, Italy, 16-18 June 2016.

36. Polska, A. Oceny estetyczne krajobrazu. Niematerialne Wartości Krajobrazów Kulturowych (Aesthetic landscape assessments. Intangible Values of Cultural Landscapes). In Prace Komisji Krajobrazu Kulturowego; Komisja Krajobrazu Kulturowego PTG: Sosnowiec, Poland, 2011; Volume 15, pp. 185-192.

37. Bell, P.A.; Greene, T.C.; Fisher, J.D.; Baum, A. Environmental Psychology; Harcourt College Publishers: New York, NY, USA, 2001.

38. Sevenant, M.; Antrop, M. Cognitive attributes and aesthetic preferences in assessment and differentiation of landscapes. $J$. Environ. Manag. 2009, 90, 2889-2899. [CrossRef]

39. Kaltenborn, B.P.; Bjerke, T. Associations between environmental value orientations and landscape preferences. Landsc. Urban Plan. 2002, 59, 1-11. [CrossRef]

40. Merriman, P.; Webster, C. Travel projects: Landscape, art, movement. Cult Geogr 2009, 16, 525-535. [CrossRef]

41. Erikstad, L.; Uttakleiv, L.A.; Halvorsen, R. Characterisation and mapping of landscape types, a case study from Norway. Belgeo. Rev. Belg. Géogr. 2015, 3, 1-14. [CrossRef]

42. Aristotle. Poetics; Dover Publications Inc.: New York, NY, USA, 2000.

43. Wojciechowski, K. Problemy percepcji i oceny estetycznej krajobrazu (Problems of Perception and Aesthetic Evaluation of Landscape); Uniwersytet Marii Curie-Skłodowskiej: Lublin, Poland, 1986.

44. Beery, T.; Jönsson, K.I.; Elmberg, J. From Environmental Connectedness to Sustainable Futures: Topophilia and Human Affiliation with Nature. Sustainability 2015, 7, 8837-8854. [CrossRef]

45. Orians, G.H.; Heerwagen, J.H. Evolved responses to landscapes. In The Adapted Mind: Evolutionary Psychology and the Generation of Culture; Barkow, J.H., Cosmides, L., Tooby, J., Eds.; Oxford University Press: Oxford, UK, 1992; pp. 555-579.

46. Buss, D.M. Evolution of Desire. Strategies of Human Mating; Basic Books, Perseus Books Group: New York, NY, USA, 2003.

47. Falk, J.H.; Ballin, J.D. Evolutionary Influence on Human Landscape Preference. Environ. Behav. 2010, 42, 479-493. [CrossRef]

48. Klasios, J. Evolutionizing human nature. New Ideas Psychol. 2016, 40, 103-114. [CrossRef]

49. Townsend, J.; Barton, S. The Impact of Ancient Tree Form on Modern Landscape Preferences. Urban For. Urban Green. 2018, 34, 205-216. [CrossRef]

50. Moura, J.M.B.; Ferreira, W.S., Jr.; Silva, T.C.; Albuquerque, U.P. The Influence of the Evolutionary Past on the Mind: An Analysis of the Preference for Landscapes in the Human Species. Front. Psychol. 2018, 9, 2485. [CrossRef]

51. Mangone, G.; Dopko, R.L.; Zelenski, J.M. Deciphering landscape preferences: Investigating the roles of familiarity and biome types. Landsc. Urban Plan. 2021, 214, 104189. [CrossRef] 
52. Christian, C.S. The concept of land units and land systems. In Proceedings of the Ninth Pacific Science Congress, Bangkok, Thailand, 18 November-9 December 1958; Volume 20, pp. 74-81.

53. Wendland, Z. Historia Filozofii. Od Szkoty Jońskiej do Postmodernizmu (History of Philosophy. From the Ionian School to Postmodernism); Wydawnictwo SGGW: Warszawa, Poland, 2003.

54. Farina, G. Some reflections on the phenomenological method. Dialogues Philos. Ment. Neuro Sci. 2014, 7, 50-62.

55. Petrović, E.K.; Marques, B.; Perkins, N.; Marriage, G. Phenomenology in Spatial Design Disciplines: Could it Offer a Bridge to Sustainability? In Advancements in the Philosophy of Design; Springer: Cham, Switzerland, 2018; pp. $285-316$.

56. Aaker, J.L. Dimensions of Brand Personality. J. Mark. Res. 1997, 34, 347-356. [CrossRef] 